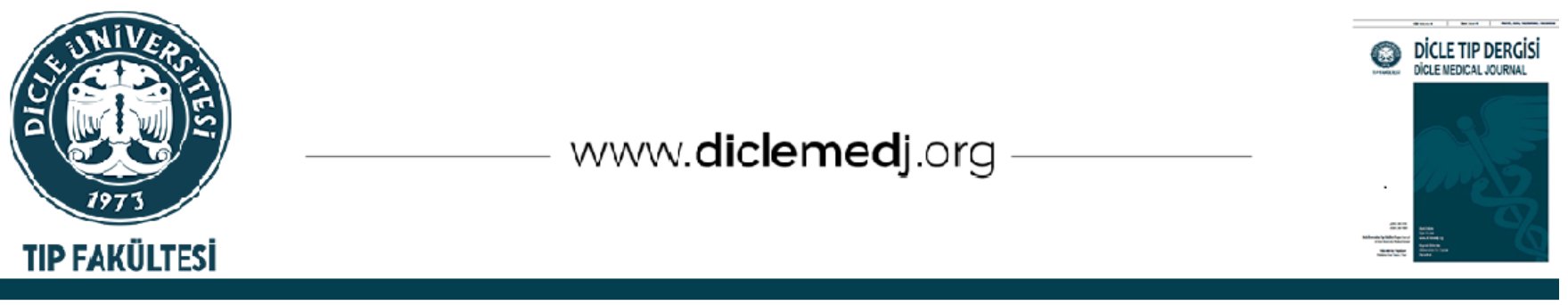

Original Article / Özgün Araştırma

\title{
Irritable Bowel Syndrome In Multiple Sclerosis Patients and Its Relation To Attacks
}

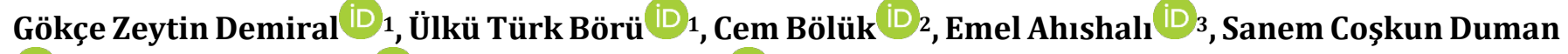 \\ iD 4, Bahadır H Demiral iD 5, Mustafa Taşdemir iD 6
}

1 Afyonkarahisar University of Health Sciences, Department of Neurology, Afyon, Turkey

2 İstanbul University-Cerrahpaşa, Cerrahpaşa Faculty of Medicine, Department of Neurology and Clinical Neurophysiology, Istanbul, Turkey

3 Koç University, Department of Gastroenterology, Istanbul, Turkey

4 Koç University, Department of Neurology, Istanbul, Turkey

5 Afyonkarahisar Public Health Center, Department of Family Medicine, Afyonkarahisar, Turkey

6 Istanbul Medeniyet University, Department of Public Health, Istanbul, Turkey

Received: 07.02.2021; Revised: 13.04.2021; Accepted: 14.04.2021

\begin{abstract}
Objective: Knowledge about bidirectional microbiome-gut-brain interactions has gradually increased in multiple sclerosis (MS) and many other diseases. The aim of this study is to determine the prevalence of irritable bowel syndrome (IBS) in MS patients, to compare with a control group and to identify the relationship between MS attacks and gastrointestinal (GI) symptoms.

Methods: Patients with at least a two-year diagnosis of relapsing-remitting MS (RRMS) from our outpatient clinic were included in the study. The duration of disease, expanded disability status scale and time of MS attacks were recorded. ROME- IV criteria were used for diagnosis of IBS. Results were compared with the control group. IBS symptoms prior to, during and after an attack were recorded and their relationship to MS attacks was investigated.

Results: 93 RRMS patients and 101 controls were included in this study. The prevalence rate of IBS was found to be $16.1 \%$ (n=15) in MS patients and $8.9 \%(n=9)$ in the control group. No significant difference can be found in IBS prevalence rate between MS patients and controls $(\mathrm{p}=0.127)$. MS attacks had no significant effect on constipation, diarrhea, abdominal pain and distention.

Conclusion: This study showed that MS patients have a similar IBS prevalence to the control group. In addition, MS attacks have no significant effect on GI symptoms.
\end{abstract}

Keywords: Abdominal Pain, Constipation, Diarrhea, Irritable Bowel Syndrome, Multiple Sclerosis

DOI: 10.5798/dicletip.944374

Correspondence / Yazıșma Adresi: Cem Bölük, Istanbul University Cerrahpaşa-Cerrahpaşa Faculty of Medicine, Department of Neurology, Fatih, Istanbul, Turkeye-mail: cem_boluk@hotmail.com 


\section{Multipl Skleroz Hastalarında İrritabl Barsak Sendromu ve Ataklarla Olan İlişkisi}

Öz

Amaç: Multipl skleroz (MS) ve diğer hastalıklarda; mikrobiyom-barsak ve beynin iki yönlü etkileşimi konusundaki bilgi birikimi giderek artmaktadır. Bu çalışmanın amacı MS hastalarında irritabl barsak sendromu prevalansını belirlemek, kontrol grubu ile karşılaştırmak ve MS atakları ile gastrointestinal semptomlar arasındaki ilişkiyi belirlemektir.

Yöntemler: Kliniğimizce en az 2 yıldır yineleyici MS (RRMS) teşhisi ile izlenen hastalar çalışmaya dâhil edildi. Hastalık süresi, özürlülük skalası (EDSS) ve MS atak zamanları kaydedildi. Irritabl barsak sendromu tanısında Roma-IV kriterleri kullanıldı. Sonuçlar kontrol grubu ile karşılaştırıldı. MS atakları öncesindeki, atak sırasındaki ve sonrasındaki gastrointestinal semptomlar kaydedilerek MS atakları ile ilişkisi araștırıldı.

Bulgular: 93 RRMS hastası ve 101 kontrol çalışmaya dâhil edildi. MS hastalarında irritabl barsak sendromu prevalansı \%16,1 (n=15) bulunurken, kontrol grubunda \%8,9 (n=9) bulundu. İrritabl barsak sendromu sıklığı açısından MS hastaları ve sağlıklı kontroller arasında istatistiksel olarak anlamlı farklılık izlenmedi $(\mathrm{p}=0,127)$. MS ataklarının ishal, kabızlık, şişkinlik ve karın ağrısı üzerine anlamlı etkisi bulunamad.

Sonuç: Bu çalışma MS hastalarındaki irritabl barsak sendromu sıklığının sağlıklı kontroller ile benzer olduğunu göstermiştir. Ayrıca MS ataklarının gastrointestinal semptomlar üzerine anlamlı etkisi yoktur.

Anahtar kelimeler: İshal, kabızlık, karın ağrısı, irritabl barsak sendromu, multipl skleroz.

\section{INTRODUCTION}

Comorbidity has become a subject of increasing interest in multiple sclerosis (MS) due to the emergence of evidence that comorbidity is linked with diagnostic delay, the progression of disability, health-related quality of life and the progression of lesion burden on magnetic resonance imaging (MRI)1-5. With that said, the reported prevalence of comorbidity in MS varies greatly, this depends on the number and type of conditions considered along with the characteristics of the study population ${ }^{6,7}$.

Neurologists in their examination of MS patients often focused on sensorial and motor symptoms. Over the last twenty years, gastrointestinal (GI) symptoms have been noticed and used in patient assessments. GI symptoms such as constipation, dysphasia and fecal incontinence are observed in the majority of MS patients. By means of these, connections between the intestine and the brain have been researched. Knowledge about bidirectional microbiome-gut-brain interactions has gradually increased in MS and many other diseases. It is indicated that a disordered brain may cause gastrointestinal symptoms by affecting motility, acid secretion and mucosal immune response through sympathetic and parasympathetic branches of its autonomic nervous system ${ }^{8-10}$.

Studies on irritable bowel syndrome (IBS) in MS patients are limited and these studies were carried out alongside other comorbid conditions. The results of these studies recorded a changeable prevalence rate of IBS in MS patients ${ }^{11}$.

The first aim of this study is to validate the results of previous studies by investigating and comparing the prevalence rates of IBS in MS patients and controls. The second aim is to bring gastrointestinal symptoms of MS patients to light by investigating the relationship between GI symptoms and MS attacks.

\section{METHODS}

The MS patients who participated in this study were recruited from the outpatient clinic of a university hospital. All participating patients were existing patients at our clinic and were already being followed by our clinic and our neurologists. 
The Rome- IV criteria were used to diagnose IBS $^{12}$. A questionnaire was prepared by deriving Turkish validated form of the adult functional GI disorders Questionnaire ${ }^{13}$. The questionnaire includes 5 subgroups one of which is aimed at IBS.

The IBS diagnostic criteria: Recurrent abdominal pain at least 1 day per week in the last 3 months (on average), associated with 2 or more of the following criteria: 1) related to defecation, 2) associated with a change in frequency of stool, 3) associated with a change in form of stool. Criteria are currently fulfilled 3 months with symptom onset at least 6 months prior to diagnosis.

Inclusion criteria: Patients above 17 years old and having a minimum of a 2-year RRMS diagnosis were included. The control group consisted of hospital employees over the age of 18 with no history of systemic illness and who do not currently take any medication.

Exclusion criteria: The presence of alarm symptoms (persistent constipation, persistent diarrhea, anemia, fever, weight loss, a family history of malignancy, high ESR), pregnancy, chronic medical disease, persistent drug usage, teriflunamide and dimethyl fumarate usage for MS patients.

The diagnostic criteria of McDonald were used for the diagnosis of MS ${ }^{14}$. Kurtzke's Expanded Disability State Score (EDSS) was used to assess the severity of the disease ${ }^{15}$. The patients' age, gender, duration of disease, EDSS score and Disease-Modifying Drugs usage were recorded. GI symptoms (constipation, abdominal distention, abdominal pain and diarrhea) experienced 1 week prior to, during and 8 weeks after MS attacks were also recorded. In case of an MS attack, patients were evaluated before any steroid use.

\section{Statistical Analysis}

The sample size was calculated by OpenEpi version 3.01. Sample size was calculated minimum as 98 patients in each group with 95\% two-sided significance level and 80\% power if the percentage of IBS prevalence were $19.3 \%$ with MS and $6 \%$ with a control group. The assumptions regarding the estimated between-group difference were based on epidemiological studies ${ }^{11}$.

Statistical analysis was performed using the PASW Statistics 18.0 software. Frequency distributions and percentages were calculated. T-test, chi-square test and Cochran's test were performed. Results were considered to be statistically significant at the level of $p<0.05$

During the study, 110 MS patients and 110 healthy controls were assessed for eligibility. 17 persons declined to participate. The participation rate was $92.3 \%$. 9 participants were excluded because of pregnancy, medication overuse and malignancy. Patients and healthy controls were matched for age and sex. 93 RRMS patients and 101 controls were included in this study. This study was approved by the local ethics committee. The approval number is $2016 / 514 / 93 / 2$.

\section{RESULTS}

93 RRMS patients and 101 controls were included in this study. All patients and healthy controls were from the Turkish population. The mean age of MS patients was $36.84 \pm 10.6$ years, 65 patients were female and 28 patients were male. The female/male ratio was 2.3. The mean age of controls was $36.84 \pm 9.0$ years, 77 were female and 24 of them male. The female/male ratio was 3.2. There was no statistically significant difference between the mean age of the MS patients and healthy controls $(\mathrm{p}=0.998)$. Similarly, there were no significant differences between the female/male ratio of the two groups $(p=0.319)$. The demographical and clinical characteristics of the two groups are shown in Table 1. Disease-modifying treatments of MS patients are shown in Table 2. 
Table I: The demographical and clinical characteristics of the two groups.

\begin{tabular}{|llll|}
\hline \multicolumn{3}{|c}{ MS } & \multicolumn{2}{c|}{ Controls(n=101) } \\
& Patients(n=93) & & values \\
\hline Mean Age & $36.84+10.6$ & $36.84 \pm 9.0$ & $0.998^{1}$ \\
Female/male & & 3.2 & 0.3192 \\
ratio & 2.3 & & \\
IBS & & & 0.1273 \\
prevalence & $16.1 \%$ & $8.9 \%$ & \\
(\%) & & & \\
\hline
\end{tabular}

p1: student t test, p2: chi-square test, p3: chi-square test

Table II: Disease Modifying Treatments of MS patients

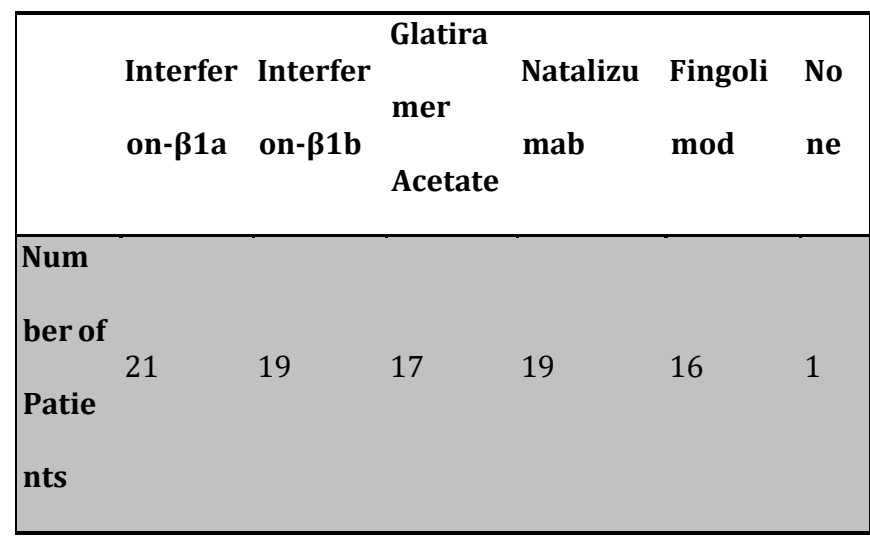

The prevalence rate of IBS in MS patients was found to be $16.1 \%(n=15)$ and $8.9 \%(n=9)$ in the control group. There was no statistically significant difference in the IBS prevalence rate between MS patients and controls ( $p=0.127)$.

\section{Factors related to IBS in MS patients}

In MS patients, the mean duration of the disease was found to be $6.1 \pm 4.7$ years. There was no statistically significant difference between the duration of MS in those with IBS and those without $(p=0.567)$. The mean EDSS of the patients was 3.1 \pm 1.4 . The difference in EDSS in MS patients with IBS and those without was not statistically significant $(\mathrm{p}=0.894)$.

\section{Evaluation of GI symptoms}

Constipation was observed in 29 patients one week before attacks whilst observed in 26 patients during attacks. It was observed in 27 patients 8 weeks after attacks. There was no statistically significant difference $(p=0.717)$.

Diarrhea was seen in 10 patients one week prior to attacks. It was recorded in 10 patients during attacks. It was seen in 5 patients 8 weeks following attacks. There was no statistically significant difference $(\mathrm{p}=0.082)$.

Abdominal pain was observed in 16 patients 1 week prior to attacks and in 14 patients during attacks. 10 patients experienced these symptoms 8 weeks following attacks. There was no statistically significant difference $(p=0.193)$.

Abdominal distention was experienced in 25 patients 1 week prior to attacks and 25 patients experienced this during attacks. 22 patients experienced abdominal distention 8 weeks following attacks. There was no statistically significant difference $(\mathrm{p}=0.651)$.

The relationship between gastrointestinal symptoms and MS attacks is illustrated in Table 3.

Table III: The relationship between gastrointestinal symptoms and MS attacks

\begin{tabular}{|c|c|c|c|c|}
\hline & $\begin{array}{l}\text { Prior to } \\
\text { Attacks }\end{array}$ & $\begin{array}{l}\text { During } \\
\text { Attacks }\end{array}$ & $\begin{array}{l}\text { After } \\
\text { Attacks }\end{array}$ & p value ${ }^{*}$ \\
\hline $\begin{array}{l}\text { Constipation n, } \\
(\%)\end{array}$ & $29,(31.2 \%)$ & $26,(27.9 \%)$ & $27,(29.0 \%)$ & 0.717 \\
\hline Diarrhea n, (\%) & $10,(10.8 \%)$ & $10,(10.8 \%)$ & $5,(5.4 \%)$ & 0.082 \\
\hline $\begin{array}{l}\text { Abdominal Pain } \\
\text { n, (\%) }\end{array}$ & $16,(17.2 \%)$ & $14,(15.1 \%)$ & $10,(10.8 \%)$ & 0.193 \\
\hline Distention n, (\%) & $25,(26.9 \%)$ & $25,(26.9 \%)$ & $22,(23.7 \%)$ & 0.651 \\
\hline
\end{tabular}

Our study shows no difference in the IBS prevalence rate between MS patients and the control group. However, even though the prevalence rate of IBS in MS patients is not statistically significant, its frequency is higher in MS patients. Disease duration and severity have 
no link to IBS in MS patients. Results indicate no correlation between GI symptoms such as constipation, diarrhea and abdominal distention and MS attacks. Although the results do not support any statistical link between GI symptoms and MS attacks, symptoms are shown to decrease following an attack.

There are two IBS prevalence studies carried out on the Turkish adult population. One of them was conducted as a face-to-face study in Sivas city center (Middle Anatolia) in 2003. In this study, the IBS prevalence rate was recorded as $19.1 \%{ }^{16}$. The second study was a selfreported study carried out in 2004 in an urban area in Elazı̆ city close to Sivas. Their study recorded that the prevalence rate of IBS was $6.3 \%{ }^{17}$. Both studies used the Rome-II diagnostic criteria. The use of Rome-II diagnostic criteria which covers a longer duration of abdominal pain may be one of the reasons for the difference in prevalence rates. Our control group prevalence rate of $8.1 \%$ was very similar to the prevalence rate in the Elazığ study.

The other prevalence studies on IBS in MS patients are mainly based in Western countries. None of these studies excluded other comorbidities such as hypertension, diabetes mellitus and regular medicine use. A population-based study showed that all GI symptoms were more frequent in diabetic patients than the control groups ${ }^{18}$. In addition, it has been reported that antihypertensive drugs may have an effect on intestinal motility along with kidney ${ }^{19,20}$.

Marrie et al. found that IBS is common in the MS population and occurs more than accepted when compared to the general population ${ }^{11}$. $\mathrm{T}$ lymphocytes might be responsible for this phenomenon and the pathogenesis with the defects of Fas protein ${ }^{21}$. Some studies on gastrointestinal symptoms in MS patients recorded a $9.4 \%$ to $19.3 \%$ rate after an MS diagnosis $22-24$. A population-based study reported a prevalence of $12.2 \%$ whilst another recorded a $1.09 \%$ prevalence rate at MS symptoms onset increasing to $1.6 \%$ at MS diagnosis ${ }^{25,26}$. A self-reported study in MS patients recorded at least one co-morbidities in $66 \%$ of all participants. Most commonly recorded comorbidities were \%37 hypercholesterolemia, \%30 hypertension, $\% 16$ arthritis, \%13 IBS, \%13 lung disease ${ }^{24}$. A study indicated a $5.9 \%$ IBS prevalence rate in all MS types while using medical records. The same study showed a $9.4 \%$ IBS prevalence when using the questionnaire 22 .

It is very difficult to compare our results with other studies because none of these studies excluded other comorbidities which can have an effect on gastrointestinal symptoms. In addition, the diagnostic criteria and methods of their studies are different.

\section{Limitations of the study}

This was a retrospective study that adopted a self-reported methodology. MS patients who had cognitive dysfunction may have had recall problems. Also, the selection of healthy controls may create a bias. Another limitation is that psychiatric evaluation of patients and data about physical activities that could affect IBS are not available. Additionally, the effects of different disease-modifying therapies on IBS symptoms have not been investigated.

\section{Strengths of the study}

A major strength is that this study was carried out by a neurologist using Rome-IV diagnostic criteria. Another additional strength is that all other comorbidities were excluded.

\section{CONCLUSION}

This study recorded that the prevalence rate of IBS in MS patients does not differ much from the control group. There is no relationship between MS attacks and IBS symptoms in patients. Further prospective studies investigating gastrointestinal symptoms and consisting of 
more participants may shed more light on this issue.

\section{ACKNOWLEDGEMENTS}

We thank our colleagues from the department of gastroenterology and neurology who provided insight and expertise that greatly assisted the research. We also thank Jessica Wells for her assistance with language.

Ethics Committee Approval: This study was approved by the local ethics committee. The approval number is 2016/514/93/2.

Declaration of Conflicting Interests: The authors declare that they have no conflict of interest.

Financial Disclosure: No financial support was received.

\section{REFERENCES}

1. Marrie RA, Horwitz R, Cutter G, et al. Comorbidity delays diagnosis and increases disability at diagnosis in MS. Neurology 2009; 72: 117-24. doi: 10.1212/01.wnl.0000333252.78173.5f.

2. Marrie RA, Rudick R, Horwitz R, et al. Vascular comorbidity is associated with more rapid disability progression in multiple sclerosis. Neurology 2010; 74:

1041-7.

doi:

10.1212/WNL.0b013e3181d6b125.

3. Köseoglu M, Gözübatik Çelik RG, Tütüncü M, Erbaş B. Quality of Life in Multiple Sclerosis: Are Depressive Findings as Effective as Physical Disability? Dicle Med J 2020; 47: 712-9. doi: 10.5798/dicletip.800284.

4. Warren SA, Turpin KVL, Pohar SL, Jones CA, Warren KG. Comorbidity and health-related quality of life in people with multiple sclerosis. Int J MS Care 2009; 11: 6-16. doi: 10.7224/1537-2073-11.1.6.

5. Weinstock-Guttman B, Zivadinov R, Horakova D, et al. Lipid profiles are associated with lesion formation over 24 months in interferon- $\beta$ treated patients following the first demyelinating event. J Neurol Neurosurg Psychiatry 2013; 84: 1186-91. doi: 10.1136/jnnp-2012-304740.
6. Fromont A, Binquet C, Rollot F, et al. Comorbidities at multiple sclerosis diagnosis. J Neurol 2013; 260: 2629-37. doi: 10.1007/s00415-013-7041-9.

7. Kang JH, Chen YH, Lin HC. Comorbidities amongst patients with multiple sclerosis: A population-based controlled study. Eur J Neurol 2010; 17: 1215-9. doi: 10.1111/j.1468-1331.2010.02971.x.

8. Guan XL, Wang H, Huang HS, Meng L. Prevalence of dysphagia in multiple sclerosis: a systematic review and meta-analysis. Neurol Sci 2015 May; 36: 671-81. doi: 10.1007/s10072-015-2067-7.

9. Nusrat S, Gulick E, Levinthal D, Bielefeldt K. Anorectal dysfunction in multiple sclerosis: a systematic review. ISRN Neurol 2012; 2012: 376023. doi: 10.5402/2012/376023.

10. Mayer EA, Savidge T, Shulman RJ. Brain-gut microbiome interactions and functional bowel disorders. Gastroenterology 2014; 146: 1500-12. doi: 10.1053/j.gastro.2014.02.037.

11. Marrie RA, Reider N, Stuve O, et al. The incidence and prevalence of comorbid gastrointestinal, musculoskeletal, ocular, pulmonary, and renal disorders in multiple sclerosis: a systematic review. Mult Scler 2015; 21: 332-41. doi: $10.1177 / 1352458514564488$.

12. Mearin F, Lacy BE, Chang L, et al. Bowel Disorders. Gastroenterology 2016; 18: S00165085(16)00222-5. doi: 10.1053/j.gastro.2016.02.031.

13. Özgürsoy Uran BN, Vardar R, Karadakovan A, Bor $\mathrm{S}$. The Turkish version of the Rome III criteria for IBS is valid and reliable. Turk J Gastroenterol 2014; 25 : 386-92. doi: 10.5152/tjg.2014.4774.

14. Polman $\mathrm{CH}$, Reingold SC, Banwell $\mathrm{B}$, et al. Diagnostic criteria for multiple sclerosis: 2010 revisions to the McDonald criteria. Ann Neurol 2011; 69. 2: 292-302. doi: 10.1002/ana.22366.

15. Kurtzke JF. Rating neurologic impairment in multiple sclerosis an expanded disability status scale (EDSS). Neurology 1983; 33: 1444-52. doi: 10.1212/wnl.33.11.1444.

16. Karaman N, Türkay C, Yönem O. Irritable bowel syndrome prevalence in city center of Sivas. Turk J Gastroenterol 2003; 14: 128-31. 
17. Celebi S, Acik Y, Deveci SE, et al. Epidemiological features of irritable bowel syndrome in a Turkish urban society. J Gastroenterol Hepatol 2004; 19: 738-43. doi: 10.1111/j.1440-1746.2004.03367.x.

18. Bytzer P, Talley NJ, Leemon M, et al. Prevalence of gastrointestinal symptoms associated with diabetes mellitus: a population-based survey of 15 000 adults. Arch Intern Med 2001; 161: 1989-96. doi: 10.1001/archinte.161.16.1989.

19. Patten GS, Abeywardena MY. Effects of antihypertensive agents on intestinal contractility in the spontaneously hypertensive rat: angiotensin receptor system downregulation by losartan. J Pharmacol Exp Ther 2017; 360. 2: 260-6. doi: 10.1124/jpet.116.237586.

20. Yakar B, Demir M. Evaluation of Adherence to Antihypertensive Drug Treatment Affecting Factors in Patients with Chronic Renal Failure. Dicle Med J 2019; 46: 685-96. doi: 10.5798/dicletip.661259.

21. Duran GG, Melek IM, Duman T, Gunesacar R. Investigation of the Relationship Between Serum Solubl Fas (sFas), Soluble Fas Ligand (sFasL) Levels and FAS-FASLG Polymorphisms in Patients with Multiple Sclerosis. Dicle Med J 2020; 47: 331-9.
22. Horton M, Rudick RA, Hara-Cleaver C, Marrie RA. Validation of a Self-report comorbidity questionnaire for multiple sclerosis. Neuroepidemiology 2010; 35: 83-90. doi: 10.1159/000311013.

23. Levinthal DJ, Rahman A, Nusrat $S$, et al. Adding to the burden: gastrointestinal symptoms and syndromes in multiple sclerosis. Mult Scler Int 2013: 319201. doi: 10.1155/2013/319201.

24. Marrie R, Horwitz R, Cutter G, et al. Comorbidity, socioeconomic status, and multiple sclerosis. Mult Scler 2008; 14: 1091-1098. doi: $10.1177 / 1352458508092263$.

25. Marrie RA, Yu BN, Leung S, et al.; CIHR Team in the Epidemiology and Impact of Comomrbidity on Multiple Sclerosis. The utility of administrative data for surveillance of comorbidity in multiple sclerosis: a validation study. Neuroepidemiology 2013; 40: 85-92. doi: 10.1159/000343188.

26. Marrie RA, Horwitz RI, Cutter G, Tyry T, Vollmer T. Association between comorbidity and clinical characteristics of MS. Acta Neurol Scand 2011;124:135-141. doi: 10.1111/j.16000404.2010.01436.x. 